\title{
Perinatale infeksjoner: Er det fortsatt et aktuelt tema i Norge?
}

\author{
Babill Stray-Pedersen \\ Kvinneklinikken, Rikshospitalet, 0027 Oslo
}

\begin{abstract}
SAMMENDRAG
Infeksjonspanoramaet forandres stadig. Artikkelen gir en oversikt over de aktuelle infeksjoner som kan overføres fra mor til foster under svangerskapet og ved fødselen. Hyppighet og forebyggende tiltak i Norge drøftes spesielt.
\end{abstract}

\section{INTRODUKSJON}

Det er nå snart 25 år siden en amerikansk pediater lanserte akronymet TORCH hvor hver bokstav skulle representere en medfødt infeksjon: T- Toxoplasmose, R- Rubella, C- Cytomegalovirus, H- Herpes, dessuten $\mathrm{O}$ for "others" som skulle omfatte andre infeksjoner (1). Navnet var ment å skulle være en fakkel for barneleger slik at man ved uklare sykdomsbilder i nyfødtperioden skulle huske at det fantes forskjellige infeksjoner som kunne bli overført fra mor til barn. Felles for disse infeksjonene var at den gravide hadde få eller ingen sykdomstegn. Likevel kunne det smitteførende agens overføres til fosteret enten hematogent eller direkte ved kontakt under fødsel. Sykdomsbildet hos den nyfødte kunne variere fra en akutt generell infeksjon med sepsis, pneumoni og meningitt til en helt asymptomatisk tilstand hvor komplikasjonene oppdages først senere i barne og ungdomsårene i form av øye, øre og hjerneskader (1).

Men infeksjonspanoramaet er i stadig forandring. De mest vanlige infeksjonene for 20-30 år siden er nå erstattet av andre. Økt kunnskap innen immunologi, bedre diagnostiske muligheter, flere og mer bredspektrete antibiotika samt forskjellige screening- og vaksinasjonsprogram kan ha bidratt til forandringen i infeksjonsspekteret. Syfilis og rubella som tidligere var en hyppig årsak til fosterskader, er nå nærmest utryddet $\mathrm{i}$ Norge. Infeksjoner med f.eks hepatitt B virus, humant papilloma virus (HPV), human immunsvikt virus (HIV), gruppe B-streptokokker, Chlamydia trachomatis og bakteriell vaginose kan nå ha betydning for svangerskapet, og det blivende barnet.

Det hevdes derfor i dag at TORCH-navnet burde glemmes. Imidlertid er det slik at de fleste "nye" infeksjonene begynner på $\mathrm{H}$ eller $\mathrm{C}$ og således kan inkluderes i TORCH-komplekset. Navnet kan derfor fortsatt være en fakkel som minner oss på at maternelle infeksjoner eksisterer og kan skade fosteret (2).

I dagens Norge er følgende infeksjoner aktuelle:
Syfilis

Serologisk syfilis-kontroll av gravide ble innført i vårt land i 1947. Syfilis forekommer nå sjelden i Norge. I de siste årene har kun 6-7 nye tilfeller blitt identifisert årlig, derav ingen gravide. Men situasjonen ute $\mathrm{i}$ verden er en annen. I enkelte land i Afrika og Asia er fra 1 til $5 \%$ av de gravide infisert, i de Baltiske land og Russland øker hyppigheten av syfilis dramatisk $(3,4)$. Imidlertid er medfødt syfilis sjeldent fordi screening av gravide foregår i de fleste land (5). Syfilis-testen er billig og penicillinbehandlingen i svangerskapet er meget effektiv i å forebygge medfødt syfilis. Derfor fortsetter syfilis-screeningen i svangerskapet også i land hvor infeksjonen nesten er utryddet.

\section{Gonore}

Ved vaginal forløsning kan gonoroisk infeksjon overføres fra mor og føre til øyeinfeksjon hos barnet. Ubehandlet kan dette forårsake arr i hornhinnen og blindhet (5). Crede's profylakse (rutinemessig lapisdrypping av øynene til de nyfødte) ble innført i begynnelsen av dette århundret. I 1984 foreslo Helsedirektoratet at denne profylaksen kunne opphøre i Norge i og med at forekomsten av gonore hadde sunket drastisk. I 1995 ble knapt 200 nye tilfelle registrert i den voksne befolkning i Norge, hvorav kun 1/4 var hos kvinner. Gonoroisk konjuntivitt hos nyfødte har variert fra 0-2 tilfeller årlig i de siste 10 år. Men i utviklingsland er infeksjonen fortsatt hyppig. Tyskland har nettopp evaluert neonatal-profylaksen og konkludert med at i deres land er det viktig å fortsette lapisdryppingen av øynene til de nyfødte (6).

\section{Chlamydia trachomatis}

I Norge ble man først oppmerksom på Chlamydiainfeksjonen i slutten av 1970-årene samtidig med at forekomsten av salpingitt økte. Chlamydiainfeksjonen er som oftest symptomfri, mikroben overføres seksuelt og predileksjonsstedene er cervix og urethra. Ubehandlet vil opptil $15 \%$ av smittede kvinner utvikle 
salpingitt og bekkenperitonitt. Infertilitet, ektopisk svangerskap og kroniske smerter er hyppige sene komplikasjoner. Genital Chlamydia-infeksjon er i dag nominativt meldepliktig. Behandlende lege er pålagt smitteoppsporing, og medikamentene fås på blå resept. I Norge har man de siste 10 år aktivt forsøkt å begrense infeksjonen ved å innføre screening før abortinngrep, screening av gravide og kvinner som ønsker prevensjon. Forekomsten er blitt drastisk redusert de siste år: blant abortsøkende i Oslo ble Chlamydia påvist hos 12\% i 1984 (2), mens i 1995 fantes mikroben kun hos $3 \%$. De forebyggende tiltak syntes derfor å hatt effekt.

Dersom en gravid kvinne har Chlamydia-infeksjon, kan fosteret smittes under den vaginale forløsningen og barnet kan utvikle konjuntivitt eller pneumoni. Tilstandene debuterer sent i nyfødtperioden, oftest mer enn 3 uker etter fødselen. I dagens Norge anbefales Chlamydia-screening av kvinner under 25 år som oppsøker helsevesenet for prevensjon, for graviditet eller for abortsøknad (7). I tillegg anbefales Chlamydiaundersøkelse ved partnerskifte, og ved utredning av dysuri uten påviselig bakterieuri. Gravide behandles med amoxicillin $500 \mathrm{mg}$ x 3 daglig i 7 dager.

\section{Herpes genitalis}

Genital herpes er vanlig og skyldes først og fremst Herpes simplex virus type 2 (HSV-2). Blant fødende på Aker sykehus i Oslo rapporteres symptomgivende herpes sykehistorie hos 2\% (2). Serologiske undersøkelser av spesifikt HSV-2 tyder imidlertid på at 15$30 \%$ av gravide (fra Sverige og USA) er smittet med genital herpes (8). Neonatal herpes er fortsatt en fryktet komplikasjon. Barnet smittes ved direkte kontakt med en infisert (symtomatisk eller asymtomatisk) fødselskanal. Uten tidlig behandling vil ca. $30 \%$ av de infiserte barna dø og ca. 20\% overleve med nevrologiske senkomplikasjoner (9). Primær infeksjon på slutten av svangerskapet er mest risikofylt med infeksjonsoverførsel til barnet fra 30 til 50\%. Hos disse kvinnene anbefales fortsatt sectio, samt acyclovir (9). Når det gjelder residiv herpes, er overføring til fosteret sjelden $(0,5-3 \%)$ selv om den gravide skiller ut virus ved fødsel (9). Dette skyldes at antistoffer fra mor beskytter fosteret. Men fordi infeksjonsmuligheten er til stede, vil fortsatt en gravid med symptomatisk residiverende herpes ved fødselen, bli forløst med keisersnitt de fleste steder (10). Nyere tids forskning har vist at profylaktisk acyklovir behandling før fødsel hindrer utbrudd og virusutskillelse under forløsning $(9,10,11)$. Acyklovir har i tillegg vist seg å være effektivt hos smittede nyfødte dersom behandlingen settes igang tidlig nok (9).

\section{HIV}

Dette viruset ble oppdaget i begynnelsen av 1980-tallet og spredningen øker fortsatt ute $\mathrm{i}$ verden. Inntil nå regner man med at 24 millioner mennesker er smittet. I Norge er ca. en halv million gravide kvinner undersøkt og nær 50 mødre er funnet HIV-positive. De fleste av disse kvinnene var kjent med sin infeksjon på forhånd. Overførselen fra mor til barn i Europa synes å være ca. $20 \%$, og HIV-smittede barn vil utvikle AIDS med rask sykdomsprogresjon i løpet av de første 2-3 leveår (12). I Norge er 47 barn født av HIV-positive mødre fulgt mer enn i 1 år og 6 barn (13\%) er HIV-smittet (13). Fosteret kan smittes transplacentært, under fødselen og gjennom morsmelk. Behandling av gravid mor med AZT tidligst mulig i svangerskapet reduserer smitterisikoen til barnet betydelig, mens andre infeksjoner samtidig i fødselskanalen (f.eks. herpes genitalis) øker smitterisikoen. Vaginal forløsning med spesielle hygieniske forholdsregler anbefales hos de AZTbehandlede gravide, mens amming frarådes i de vestlige land (12).

\section{Hepatitt B}

Globalt sett er Hepatitt B en av de vanligste alvorlige infeksjonssykdommer. I de steder hvor HBV-bærerfrekvensen er hyppig skyldes dette primært smitte under fødsel: $90 \%$ av barn født av HBeAg-positive mødre vil bli kroniske bærere, mens $40 \%$ av barna til de HBsAg-positive mødrene vil bli dette. Videre vil ca. 1/4 av disse HBAg-positive barna senere i livet utvikle hepatocellulært carsinom, en stor andel også leverkirrose (5). Vaksine ble tilgjengelig i begynnelsen av 1980-tallet og nå er vaksinering av nyfødte introdusert $\mathrm{i}$ en rekke land rundt om i verden. Effektiviteten syntes å være ca. 95\% (5). Etter hvert vil dette føre til en reduksjon i den generelle bærer-frekvensen.

I Norge anbefales screening av «risikogravide», eller gravide som kommer fra områder hvor Hepatitt B infeksjonen er hyppig, dvs. hele verden unntatt VestEuropa og USA (14). Nyfødte av HBV-positive mødre tilbys spesifikt immunglobulin og vaksine rett etter fødsel. Vaksinen gjentas 3 ganger første leveår. Transmisjon via morsmelk er beskrevet, men faren er så liten at mor kan amme. Det bør presiseres at helsepersonell på en fødeavdeling er i en spesiell risiko med stor mulighet for smitte ikke bare via blod, men også fostervann. Vaksinasjon anbefales derfor spesielt til denne gruppen (2).

\section{Hepatitt C}

Viruset smitter hovedsakelig ved blodkontakt, men seksuell overføring er beskrevet. Av voksne HCVsmittede vil $70 \%$ bli kroniske bærere hvor HCV-RNA kan påvises med PCR-teknikk. En stor del av disse vil over tid utvikle levercirrhose. Vertikal smitteoverføring til barnet under fødsel skjer i 2 til $20 \%$ hvis mor er PCR-HCV positiv. Hvorvidt behandling av mor i svangerskapet med interferon påvirker smitteoverføringen til barnet er ikke avklart (15). Økt smittefrekvens ses hos barn hvor mor samtidig er HIVpositiv. Flere perinatalt HCV-infiserte barn er identifisert i Norge. Amming tillates. Undersøkelse i svangerskapet anbefales idag av kvinner som har fått blodtransfusjon eller har hatt hepatitt, samt stoffmisbrukere og kvinner i HIV-risikogruppen med tidligere kjønnssykdommer (15). 


\section{Rubella}

Vaksinasjon mot røde hunder ble innført i Norge i 1978. Dette har hatt effekt på den gravide populasjon, slik at det blant norske gravide kvinner nå er svært få (5\%) som ikke er immune. De fleste av våre innvandrerkvinner har imidlertid ikke blitt vaksinert i sine hjemland og er fortsatt mottagelige. Rubella-virus er et av de mest velkjente teratogener med stor risiko for fosterskade dersom den gravide infiseres i første trimester. Siste år ble det kun registrert ett tilfelle blant gravide i Norge.

\section{Cytomegalovirus}

Vår kunnskap om CMV-infeksjonen er mangelfull. Mer kunnskap og også norske data trengs. I 1974 fant man at $69 \%$ av gravide i Oslo hadde CMV-antistoff (16). Både primær og residiverende infeksjon kan være skadelig for fosteret. Man regner med at 0,5 til $1 \%$ av alle nyfødte er CMV-infisert, men kun en av ti infiserte vil vise tegn til medfødt skade (psykomotorisk retardasjon, hørselsdefekter). Gancyclovir har vært prøvd ved kongenital CMV-infeksjon, men effekten er omdiskutert. Det finnes derfor i dag ingen egentlig behandling eller vaksine, det er derfor vanskelig å anbefale forebyggende tiltak annet enn god håndhygiene (5).

\section{Toksoplasmose}

Primær toxoplasma-infeksjon i graviditeten representerer en fare for barnet (17). Parasitt-overførsel skjer hos ca. $40 \%$ og er hyppigst ved infeksjon på slutten av svangerskapet. Infeksjonen er oftest asymptomatisk hos den gravide og også hos den nyfødte. Behandling i svangerskapet med pyrimetamin/sulfa og spiramycin reduserer den vertikale parasitt-transmisjonen og hemmer eller stanser sykdomsutviklingen hos fosteret. De fleste barna med kongenital toksoplasmose (> 90\%) er asymtomatiske ved fødselen, men uten behandling antas majoriteten av barna å utvikle senkomplikasjoner i form av chorioretinitt eller "minimal brain damage" (oversikt se 17).

Serologiske undersøkelser i 1992-94 (18) har vist at $11 \%$ av gravide kvinner i Norge har antistoff og er smittet før svangerskapet. Prevalensen varierte fra $13,7 \%$ i Rogaland til $6,7 \%$ i Nordland - det nordligste fylket som ble undersøkt. Prevalensen var den samme nå og for 20 år siden i Oslo (13\%) og i Møre og Romsdal (10\%) (19). Smitterisikoen er generelt lav i Norge (insidens 1,7 per 1000 seronegative kvinner), spesielt lav er insidensen i nord og i innlandsfylkene. I Osloområdet ble imidlertid 5 gravide smittet per 1000 mottagelige (18). Liknende høye tall finnes i MellomEuropa hvor serologisk svangerskapscreening med behandling av smittede gravide er innført (17). I hovedstaden med omegn må man derfor anta at toxoplasma-infeksjonen i dag er en av de hyppigste infeksjoner som kan true fosteret. Forfatteren mener derfor at toxoplasmoseundersøkelser av gravide med tre blodprøver - tatt i først trimester, i 22-24 svanger- skapsuke samt i 36-38 uke - bør fortsette i Osloområdet slik at smittede gravide kan identifiseres og behandles for å hindre kongenital infeksjon og sequele. Det viste seg videre i den landsomfattende undersøkelsen at mange av de smittede gravide hadde kliniske symptomer som ikke ble erkjent, slik som palpable lymfeknuter på halsen, influensa-symtomer eller ekstrem tretthet (18). Opptrer disse tegnene er det indikasjon for serologisk undersøkelse.

Risikofaktorer for toxoplasma-smitte i Norge er: Spising av rått eller ikke gjennomkokt/gjennomstekt kjøtt fra gris og lam samt dårlig kjøkkenhygiene (20). Rå kjøttdeig og rå kjøttfarse er også smittekilder, dessuten uvasket nedfallsfrukt. Kattunger i husholdet samt det å ha en kattekasse inne i boligen i svangerskapet er andre risikofaktorer, foruten reising til land hvor infeksjonsrisikoen er større enn i Norge. Gravide i Norge bør derfor opplyses om disse faktorene og seronegative bør ta sine forholdsregler under svangerskapet. I spesielle tilfelle slik som etter sydenreise bør kvinnen testes.

\section{Streptokokkinfeksjon}

Hos en av ti gravide kvinner påvises gruppe B streptokokker i normalfloraen i vagina (2). Frekvensen varierer fra land til land. Overførsel skjer til barnet i ca. $50 \%$ av tilfellene, men kun 1-3 per 1000 barn får alvorig GBS-infeksjon med sepsis, meningitt og pneumoni. Friske gravide med GBS-kolonisering i vagina bør ikke behandles. Men dersom en GBS-bærer har feber ved begynnende fødsel, langvarig vannavgang, eller tidligere har født barn med GBS-infeksjon, bør mor behandles med parenteral antibiotika under fødsel, og barnet vurderes for antibiotika profylakse. Klorhexidin-skylling under fødsel reduserer koloniseringen og bakterieoverførsel fra mor til barn, men er ingen behandling for et allerede infisert foster (21).

\section{Bakteriell vaginose}

I det siste årene er det blitt fokusert stadig mer på tilstanden bakteriell vaginose som påvises hos 10-15\% av kvinner i fertil alder (22). Tilstanden skyldes en forandring i det vaginale miljøet hvor den normale bakteriefloraen med melkesyre-bakteriene har blitt erstattet av en rikelig mengde med anaerobe og aerobe bakterier, inkludert Gardnerella vaginalis, Mykoplasma hominis og anaerobe s-formede bakterier. Bakteriell vaginose fremkaller en typisk illeluktende utflod. Vaginalsekretet har en basisk pH $(>4,5)$, dessuten stilles diagnosen ved at "clue-celler" påvises i direkte våtpreparat av vaginalsekret. Denne forandringen i det vaginale miljø har også vært satt i sammenheng med for tidlig fødsel og for tidlig vannavgang. I dag foreligger en rekke overbevisende studier fra forskjellige deler av verden som alle konkluderer med at sen abort og for tidlig fødsel er overrepresentert hos gravide med bakteriell vaginose tidlig i svangerskapet. Likeledes syntes spesifikk behandling (Metronidazole, clindamycin) i svangerskapet å redusere prematuritetsfrekvensen. Årsaken antas å være at de store mengder 
med bakterier som ses ved BV forandrer strukturen i de føtale hinner og initierer prostaglandin syntesen som igjen fører til økt rieaktivitet. I dag anbefales BV screening ("wet smear" eller gramfarget preparat ikke dyrkning) i svangerskapet av alle kvinner som tidligere har hatt sen abort, prematur fødsel og prematur vannavgang slik at bakteriell vaginose kan bli behandlet under graviditeten (22).

\section{Barselsfeber}

Det er nå 150 år siden Semmelweiss påviste at barselfeber var en iatrogen infeksjon hvor den fødende kvinnen ble smittet av helsepersonell som overførte mikrober fra den ene pasienten til den annen. Innføring $\mathrm{av}$ håndvask og antiseptikk $\mathrm{i}$ fødeinstitusjonen førte til at frekvensen av barselfeber sank drastisk. Fra 18951904 ble det anmeldt 1016 dødsfall av barselfeber i Norge. 50 år senere på slutten av 1940-tallet ble det registrert 27 dødsfall blant 60000 fødsler. Deretter har det vært en jevn reduksjon inntil nylig. I de siste to årene er det påvist 13 alvorlige tilfeller med gruppe A streptokokkinfeksjon blant fødende, deriblant ett dødsfall (23). Gruppe A streptokokkene kan utvikle endotoksiner, og hos barselkvinnen som har en stor sårflate i uterus, kan infeksjonen bli svært alvorlig. Det er derfor fortsatt viktig å ha god hygiene med hyppig håndvask på fødeavdelingene.

\section{KONKLUSJON}

Infeksjonspanoramet forandres fra tid til annen. Den gravide blir smittet på samme måte og med lik hyppighet som resten av befolkningen. Imidlertid vil enhver infeksjon hos den gravide være en trussel for fosteret og det nyfødte barn. Det er derfor viktig å ha et årvåkent øye til den generelle infeksjonstilstand i befolkningen, slik at eventuelt nye infeksjoner kan diagnostiseres tidlig også hos den gravide. I dag finnes effektive forebyggende tiltak og behandling mot en rekke velkjente infeksjoner. I kampen om helsekronene bør ikke dette arbeidet nedprioriteres, da forebygging av medfødte infeksjoner og komplikasjoner på lengre sikt er med på å skape fremtiden.

\section{REFERANSER}

1. Nahmias A. The TORCH syndrome of perinatal infection. Hosp Pract 1974; 9: 65-72.

2. Stray-Pedersen B. New aspects of perinatal infection. Ann Med 1993; 25: 295-300.

3. Gromyko A. WHO file: Sexually transmitted diseases (STDs) epidemic in Eastern Europe. Entre Nous 1996; 33 (September): 7-8.

4. Linglöf T, Bakasenas V, Brila A, Jögiste A. Epidemiology of infectious diseases in Estonia, Latvia and Lithuania. WHO Forum 1996; 17: 10-13.

5. Gilbert GL. Routine antenatal screening and prenatal diagnosis of vertically transmissible infections. Baillieres Clin Obstet Gynecol 1993; 7 (1): 1-23.

6. Hoyme UB. Clinical significance of Crede's prophylaxis in Germany at the present time. J Obstet Gynecol 1994; 14 (Suppl 2): 126-127.

7. MSIS-rapport, $1995,41$.

8. Nahmias AJ, Lee F, Beckman-Nahmias S. Sero-epidemiological and sociological patterns of herpes simplex virus infection in the world. Scand J Infect Dis 1990; 69: 19-36.

9. Kroon S, Whitley R (eds). Managment of strategies in herpes. PPS Europe Iltd 1995.

10. Stray-Pedersen B. Acyclovir prepartum. Lancet 1990; 336: 756.

11. Randolph AG, Hartshorn RM, Washington AE. Acyclovir prophylaxis in late pregnancy to prevent neonatal herpes: a cost-effectiveness analysis. Obstet Gynecol 1996; 88: 603-610.

12. Temmermann M. Human immunodeficiency virus and women. J Obstet Gynecol 1994; 14 (Suppl 2): 70-75.

13. Personlig meddelse, $\varnothing$. Nilsen, Folkehelsa.

14. MSIS-rapport, 1996, 31.

15. Fischler B, et al. Vertical transmission of Hepatitis C virus infection. Scand J Infect Dis 1996; 28: 353-356.

16. Czango P, Stray-Pedersen B, 1979. Upubliserte data.

17. Stray-Pedersen B. Toxoplasmosis in pregnancy. Baillieres Clin Obstet Gynecol 1993; 7 (1): 107-137.

18. Jennum PA, et al. Forebygging av medfødt toksoplasmose i Norge. Rapport fra Folkehelsa, 1996.

19. Stray-Pedersen B, Lorentzen-Styr A-M. The prevalence of toxoplasma antibodies among 11736 pregnant women in Norway. Scand J Infect Dis 1979; 11: 159-465.

20. Kapperud G, Jennum PA, Stray-Pedersen B, Melbye KK, Eskild A, Eng J. Risk factors for Toxoplasma gondii infection in pregnancy. Am J Epidemiol 1996; 144: 405-412.

21. Stray-Pedersen B, Whitelaw A, Normann EK, Grøgaard Bergan T. Prevention of group B Streptococcal infection of newborn and puerperal women. Effect of vaginal douching with chlorhexidine during childbirth. J Obstet Gynecol 1994; 14 (Suppl 2): 121-124.

22. Desmond N, Hay P. Diagnosis and management of Bacterial vaginosis. The Dipolmate 1996; 3 (1): 41-49.

23. Personlig meddelelse, Viggo Hasseltvedt, Folkehelsa. 